\title{
54
}

\section{PARTISIPASI MASYARAKAT DALAM PROGRAM PEMBERDAYAAN MASYARAKAT PNPM MANDIRI}

\author{
Oleh: \\ Dhio Adenansi, Moch. Zainuddin, \& Binahayati Rusyidi
}

Email:

dhioadenansi@gmail.com; mochzainuddin@yahoo.com; titi.rusyidi06@yahoo.com

\begin{abstract}
Abstrak
Kemiskinan merupakan masalah yang sudah terlalu kompleks di Indonesia. Fenomena ini terjadi salah satunya karena masyarakat Indonesia terlalu berpangku tangan untuk bisa mendapatkan bantuan. Masyarakat terlalu pasif dalam kondisi ini, partisipasi dan inisiatif masyarakat dalam kondisi memperbaiki kualitas kehidupannya ini masih sangat kurang. Pada kondisi ini pemerintah perlu melakukan suatu bentuk kegiatan yang dapat membantu masyarakat untuk mencapai kesejahteraannya. Namun yang perlu menjadi perhatian adalah bahwa dalam mensejahterakan masyarakat, pemerintah perlu melakukan metode pemberdayaan terhadap masyarakat. Pemberdayaan masyarakat menjadi hal yang sangat penting agar nantinya masyarakat bisa mandiri tanpa perlu lagi diarahkan atau dituntun oleh pemerintah atau para agen perubahan. Disini pemerintah tidak bisa bekerja sendiri, perlunya peran - peran pihak lain agar bisa mencapai target yang diharapkan. Pihak lain disini maksudnya seperti LSM, masyarakat itu sendiri, dan pihak lainnya.

Program pemerintah akan bisa terealisasikan dengan baik apabila dalam prosesnya pihak yang terkait mampu bekerja sama atau dengan kata lain mampu untuk berpartisipasi dalam kegiatan yang dilaksanakan pemerintah. Partisipasi menjadi hal yang sangat penting dalam hal ini. Seperti misalnya program yang dicanangkan oleh pemerintah yakni PNPM Mandiri. Pada PNPM mandiri adalah program yang dikeluarkan pemerintah dalam rangka mengentaskan masalah kemiskinan yang sudah begitu kompleksnya di Indonesia. Di program PNPM mandiri ini masyarakat terkait dituntut untuk berpartisipasi dalam proses kegiatannya. Partisipasi disini dituntut agar masyarakat terbiasa untuk bertanggung jawab atas kondisi di lingkungannya. Maka dari itu agar tumbuhnya kesadaran di masyarakat akan tanggung jawab terhadap kondisi sosialnya maka itu menjadi tanggung jawab pemerintah dan instansi terkait untuk merubah pola pikir masyarakat untuk peduli.
\end{abstract}

\section{Pendahuluan}

Kemiskinan sudah bukan lagi menjadi hal yang asing di telinga kita. Kemiskinan merupakan suatu permasalahan yang sulit untuk dipecahkan di Indonesia dan masih menjadi pekerjaan rumah yang besar untuk pemerintah. Badan Pusat Statistik di Indonesia mencatat bahwa terjadi angka penurunan jumlah kemiskinan di Indonesia. Buktinya pada tahun 2009 angka kemiskinan tercatat sebesar 32,53 juta orang, tahun berikutnya tepatnya tahun 2010 angka kemiskinan tercatat menjadi 31,02 juta orang, lalu pada tahun selanjutnya yakni 2011 angka tersebut menurun lagi menjadi 30,12 juta orang, dan tahun 2012 terjadi penurunan lagi menajdi 29,25 juta orang, serta ditahun 2013 tercatat sebanyak 28,17 juta orang (BPS, 2011 : dds.bps.go.id). Penduduk Indonesia memang mengalami penurunan angka kemiskinan, tetapi perbedaan angka kemiskinan antara di kota dengan di desa juga menjadi masalah yang sulit dipecahkan. Pada tahun 2011 saja penduduk miskin di perkotaan sebesar 9,23\% dan penduduk miskin di pedesaan sebesar $15,72 \%$. Besar angka tersebut menjelaskan bahwa 
masyarakat pedesaan mendominasi angka kemiskinan dan masyarakat miskin di Indonesia lebih tersebar di daerah pedesaan. Di daerah perkotaan sendiri pun ketidakmerataan kesejahteraan masih sering kali dijumpai terutama pada kelurahan - kelurahan yang jauh dari pusat perkotaan. Kondisi sosial ini perlu

Pemerintah terus berupaya dalam mengatasi dan memecahkan masalah kemiskinan. Pemerintah juga menjadikan masalah kemiskinan sebagai sebuah prioritas dalam pembangunan rencana kerja pemerintah tahun 2012. Salah satu upaya pemerintah dalam mengatasi masalah kemiskinan ialah dengan memunculkan sebuah kebijakan PNPM Mandiri. PNPM Mandiri merupakan program nasional penanggulangan kemiskinan terutama yang berbasis pemberdayaan masyarakat. PNPM Mandiri adalah program nasional dalam wujud kerangka kebijakan sebagai dasar pelaksanaan program-program penanggulangan kemiskinan berbasis pemberdayaan masyarakat. PNPM Mandiri bertujuan untuk meningkatkan partisipasi seluruh masyarakat, termasuk masyarakat miskin, kelompok perempuan, komunitas adat terpencil dan kelompok masyarakat lainnya yang rentan dan sering terpinggirkan ke dalam proses pengambilan keputusan dan pengelolaan pembangunan. PNPM Mandiri terdiri dari PNPM Mandiri perkotaan, PNPM Mandiri pedesaan, dan PNPM Mandiri wilayah khusus dan daerah tertinggal.

Pembangunan di perkotaan sampai saat ini masih terpusat ditengah kota dimana pembangunan tersebut dimaksudkan untuk memberi kan kesan kepada para pendatang terhadap kota tersebut. Dengan terpusatnya pembangunan di tengah kota maka daerah sekitar yang lokasinya jauh dari tengah kota menjadi luput dari perhatian pemerintah. PNPM Mandiri perkotaan ini bisa menjadi salah satu alternatif dalam memecahkan masalah kemiskinan, dengan memberdayakan daerahnya serta menciptakan masyarakat yang aktif berpartisipasi dalam pembangunan sehingga angka kemiskinan bisa dikurangi atau bahkan teratasi.

Masyarakat dalam sebuah pemerintahan sangat besar perannya, keikutsertaan atau keterlibatan masyarakat dalam kegiatan pemerintah terkait kebijakan publik yang dikeluarkan oleh pemerintah merupakan hal penentu berhasil atau tidaknya kebijakan tersebut. Pengambilan keputusan dalam sebuah kebijakan diperlukan peran serta masyarakatnya agar pemenuhan hak dari masyarakat bisa terpenuhi. Aktifnya masyarakat akan mempermudah tercapainya target pemerintah dimana target tersebut juga akan dirasakan oleh masyarakat manfaatnya. Selain masyarakat ada juga hal yang perlu diberdayakan, yakni aspek kelembagaan masyarakat. Lembaga merupakan wadah masyarakat untuk bisa ikut serta dalam sebuah kegiatan. Memanfaatkan kelembagaan yang ada atau menciptakan lembaga masyarakat merupakan langkah yang tepat mempermudahnya proses tercapainya tujuan dari kebijakan pemberdayaan masyarakat. Semua itu tetap yang menyelenggarakan adalah pihak pemerintah dan masyarakat sebagai objek yang ditujukan harus diarahkan dan diawasi agar bisa selalu dalam koridornya. Pemerintah hanya perlu mengoptimalkan daya yang ada di masyarakat dengan memfasilitasi masyarakat melalui pelayanan umum yang disediakan. PNPM mandiri sebagai alat yang disediakan pemerintah untuk masyarakat perlu diawasi dengan benar penyelenggaraannya agar masyarakat bisa menikmati pelayanan tersebut dengan nyaman.

\section{Pemberdayaan Masyarakat}

Pemberdayaan atau Empowerment secara garis besar memiliki makna memberikan bantuan kepada masyarakat agar diberdayakan atau dengan kata lain masyarakat dioptimalkan kemampuannya agar bisa mengelola kehidupan bermasyarakatnya secara mandiri. Maka pemberdayaan masyarakat adalah sebuah upaya dalam merubah masyarakat dari yang pasif menjadi aktif, masyarakat diciptakan agar menjadi mandiri, berpikir kritis serta bisa mengendalikan dan juga bertanggung jawab atas perbaikan kualitas kehidupannya.

Agar pengertian pemberdayaan dapat dipahami lebih, maka disini dipaparkan beberapa pemahaman terkait pemberdayaan menurut ahlinya ; 
Robinson (1994) menjelaskan bahwa pemberdayaan adalah suatu proses pribadi dan sosial; suatu pembebasan kemampuan pribadi, kompetensi, kreatifitas dan kebebasan bertindak. Ife (1995) mengemukakan bahwa pemberdayaan mengacu pada kata "empowerment," yang berarti memberi daya, memberi "power" (kuasa), kekuatan, kepada pihak yang kurang berdaya.

Payne (1997) menjelaskan bahwa pemberdayaan pada hakekatnya bertujuan untuk membantu klien mendapatkan daya, kekuatan dan kemampuan untuk mengambil keputusan dan tindakan yang akan dilakukan dan berhubungan dengan diri klien tersebut, termasuk mengurangi kendala pribadi dan sosial dalam melakukan tindakan. Orang-orang yang telah mencapai tujuan kolektif diberdayakan melalui kemandiriannya, bahkan merupakan "keharusan" untuk lebih diberdayakan melalui usaha mereka sendiri dan akumulasi pengetahuan, ketrampilan serta sumber lainnya dalam rangka mencapai tujuan tanpa tergantung pada pertolongan dari hubungan eksternal.

Tujuan dari pemberdayaan adalah untuk membentuk masyarakat yang mandiri. Mandiri disini maksudnya adalah kemandirian dalam berpikir lalu bertindak dan mampu mengendalikan apa yang dilakukan. Masyarakat diberdayakan agar sadar dengan apa yang dialaminya tidak hanya untuk individu dari tiap masyarakat tp masyarakat diberdayakan agar terbentuk masyarakat yang aktif dan tidak apatis lagi dengan kondisi sekitar. Terbentuknya masyarakat yang bertransformasi dari pasif menjadi aktif serta kritis akan menciptakan masyarakat yang mandiri, dengan kemandirian tersebut masyarakat nantinya tidak perlu lagi berpangku tangan atau mengandalkan lagi bantuan pemerintah dalam mengatasi permasalahan di lingkungannya. Masyarakat akan terbiasa untuk bergerak inisiatif ketika terjadi permasalahan di lingkungannya. Pemerintah juga menjadi tidak terlalu terbebani lagi oleh permasalahan yang terjadi di masyarakat.

\section{Partisipasi Masyarakat}

Partisipasi merupakan hal yang erat kaitannya dengan pemberdayaan masyarakat. Pemberdayaan masyarakat dinilai berhasil atau tidaknya terlihat dari bagaimana partisipasi masyarakatnya dalam prosesnya. Dengan melihat bagaimana partisipasi masyarakat dalam proses pemberdayaan masyarakat, nantinya akan diketahui bagaimana kondisi masyarakat tersebut dan seperti apa pola pikir masyarakat. Ketika sikap partisipasi di masyarakat sudah terbangun maka terlihatlah perkembangan pemikiran masyarakat akan sadarnya dengan kondisi mereka. Partisipasi adalah suatu kondisi dimana masyarakat ikut serta dalam proses pengidentifikasian masalah dan bagaimana cara menanganinya, keputusan atau tindakan apa yang harus diambil untuk menghadapi masalah tersebut.

Menurut Keith Davis, pengertian partisipasi adalah keterlibatan mental/pikiran atau moral/perasaan di dalam situasi kelompok yang mendorongnya untuk memberikan sumbangan kepada kelompok dalam usaha mencapai tujuan serta turut bertanggungjawab terhadap usaha yang bersangkutan. Masyarakat merupakan salah salah bagian penting yang akan berpengaruh terhadap tegaknya negara dan tercapainya tujuan nasional. Oleh karena itu, dalam diri masyarakat harus tumbuh suatu kesadaran akan keberadaannya sehingga timbul hasrat untuk turut serta bersama pemerintah dalam membangun negara. Salah satu upaya yang dapat dilakukan oleh seorang warga masyarakat adalah dengan berpartisipasi secara aktif dalam berbagai kegiatan pembangunan di wilayahnya. Partisipasi selalu dikaitkan dengan peran serta.

Mikkelsen membuat daftar atau klasifikasi dari para praktisi pembangunan mengenai arti dari partisipasi. Pertama, Partisipasi diartikansebagai pemekaan (membuat peka) pihak masyarakat untuk meningkatkan kemauan menerima dan kemampuan untuk menanggapi proyek-proyek pembangunan. Pemaknaan seperti ini agaknya kurang tepat karena memaknai partisipasi hanya sekedar meminta dukungan masyarakat terhadap semua program yang telah disiapkan. Pertemuan (rapat) dengan dalih partisipasi (minta masukan dari warga masyarakat) yang dilaksanakan tidak lebih sebagai ajang formalitas untuk menjalankan sebuah kebijakan yang telah dibuat. Hal demikian akan memunculkan partisipasi yang semu karena masyarakat tidak diberi hak untuk merancang program kecuali hanya 
sekedar diajak, dibujuk, diperintah dan bahkan dipisahkan oleh kelembagaan tertentu untuk ikut serta dalam suatu program yang telah dirancang sebelumnya.

Kedua, Partisipasi diartikan sebagai kontribusi sukarela dari masyarakat kepada proyek tanpa ikut serta dalam pengambilan keputusan. Pemaknaan ini hampir sama dengan pemaknaan yang pertama, yang membedakan adalah kontribusi sukarela masyarakat kepada proyek. Karena itu akhir capaian dari partisipasi jenis ini adalah penghematan biaya. Masyarakat harus mendukung atau ikut program-program pemerintah secara gratis dengan alasan program-program tersebut pada akhirnya digunakan untuk kepentingan masyarakat. Proyek-proyek pembangunan yang memiliki anggaran tertentu harus dapat diselesaikan melalui penghematan-penghematan. Makin banyak penghematan atau makin murah biaya suatu proyek, maka dapat diartikan makin besar pula partisipasi masyarakat. Disini partsipasi diartikan sebagai besarnya dana yang dapat dihemat atau dana yang dapat disediakan sebagai sumbangan atau kontribusi masyarakat kepada proyek-proyek pemerintah.

Ketiga, Partisipasi adalah suatu proses keterlibatan secara aktif dalam pengambilan kepurusan bersama dengan pemerintah. Pemaknaan seperti partisipasi masyarakat dalam program pengolahan sampah ini memberikan keterlibatan yang luas dalam tiap proses pembangunan yaitu mulai dari: 1). Keterlibatan pada identifikasi masalah, dimana masyarakat bersama-sama dengan para perencana atau pemegang otoritas kebijakan mengidentifikasi persoalan, mengidentifikasi peluang, potensi dan hambatan. 2). Proses perencanaan, dimana masyarakat dilibatkan secara aktif dalam penyusunan rencana dan strategi berdasar pada hasil identifikasi sebelumnya. 3). Pelaksanaan pengolahan sampah. 4). Evaluasi, yaitu masyarakat dilibatkan untuk menilai hasil pembangunan pengolahan sampah yang telah dilakukan, apakah pembangunan memberikan manfaat bagi masyarakat atau justru sebaliknya masyarakat dirugikan dengan proses yang telah dilakukan. 5). Monitoring dan 6). Mitigasi, yaitu terlibat dalam mengukur dan mengurangi dampak negatif yang diakibatkan oleh proyek yang sedang dilaksanakan.

Keempat, Partisipasi diartikan sebagai keterlibatan sukarela oleh masyarakat dalam perubahan yang ditentukannya sendiri. Inti dari partisipasi ini adalah sikap sukarela masyarakat untuk membantu keberhasilan program pembangunan yang telah ditentukan sendiri. Keterlibatan sukarela itu bisa berupa terlibat dalam proses penentuan arah, strategi dan kebijakan pembangunan, terlibat dalam memikul beban dan tanggungjawab dalam pelaksanaan pembangunan dan terlibat dalam memilih hasil dan manfaat pembangunan secara berkeadilan.

Kelima, Partsipasi adalah keterlibatan masyarakat dalam pembangunan diri, kehidupan dan lingkungan mereka. Partisipasi dalam pengertian ini sesuai dengan konsep pemberdayaan masyarakat, dimana dalam pemberdayaan masyarakat, masyarakat secara bersama-sama mengidentifikasi kebutuhan dan masalahnya, bersama-sama mengupayakan jalan keluarnya dengan jalan memobilisasikan segala sumber daya yang diperlukan serta secara bersama-sama merencanakan dan melaksanakan kegiatan untuk mencapai tujuan yang diinginkan.

Uraian diatas menjelaskan bahwa partisipasi bukan hanya sekedar keikut sertaan dalam bekerja akan tetapi partisipasi adalah bagaimana individu atau kelompok masyarakat memiliki rasa tanggung jawab terhadap kondisi sekitar mengganggap hal tersebut sebagai hal yang harus dihadapi dan diselesaikan bersama. Partisipasi merupakan sebuah sikap kerelaan untuk ikut serta dalam sebuah kegiatan. Dalam hal ini masyarakat menjadi mitra pemerintah dalam mengatasi masalah sosial yang ada. Pada kondisi ini masyarakat dalam program PNPM mandiri diajak untuk berpartisipasi dalam proses pelaksanaanya. PNPM sebagai alatnya yang disediakan pemerintah untuk masyarakat dan masyarakat diarahkan untuk bagaimana memanfaatkan PNPM mandiri ini dengan bijak.

PNPM Mandiri adalah program nasional penanggulangan kemiskinan terutama yang berbasis pemberdayaan masyarakat. Pengertian yang terkandung mengenai PNPM Mandiri adalah :

1. PNPM Mandiri adalah program nasional dalam wujud kerangka kebijakan sebagai dasar dan acuan pelaksanaan program-program penanggulangan kemiskinan berbasis pemberdayaan masyarakat. PNPM Mandiri dilaksanakan melalui harmonisasi dan pengembangan sistem 
serta mekanisme dan prosedur program, penyediaan pendampingan dan pendanaan stimulan untuk mendorong prakarsa dan inovasi masyarakat dalam upaya penanggulangan kemiskinan yang berkelanjutan.

2. Pemberdayaan masyarakat adalah upaya untuk menciptakan/meningkatkan kapasitas masyarakat, baik secara individu maupun berkelompok, dalam memecahkan berbagai persoalan terkait upaya peningkatan kualitas hidup, kemandirian dan kesejahteraannya. Pemberdayaan masyarakat memerlukan keterlibatan yang besar dari perangkat pemerintah daerah serta berbagai pihak untuk memberikan kesempatan dan menjamin keberlanjutan berbagai hasil yang dicapai.

Secara garis besarnya PNPM mandiri bertujuan untuk meningkatkan kesejahteraan dan kesempatan kerja untuk masyarakat secara mandiri. Tetapi tujuan secara khusunya dapat dijabarkan sebagai berikut :

- Meningkatnya partisipasi seluruh masyarakat, termasuk masyarakat miskin, kelompok perempuan, komunitas adat terpencil dan kelompok masyarakat lainnya yang rentan dan sering terpinggirkan ke dalam proses pengambilan keputusan dan pengelolaan pembangunan.

- Meningkatnya kapasitas kelembagaan masyarakat yang mengakar, representatif dan akuntabel.

- Meningkatnya kapasitas pemerintah dalam memberikan pelayanan kepada masyarakat terutama masyarakat miskin melalui kebijakan, program dan penganggaran yang berpihak pada masyarakat miskin (pro-poor)

- Meningkatnya sinergi masyarakat, pemerintah daerah, swasta, asosiasi, perguruan tinggi, lembaga swadaya masyarakat, organisasi masyarakat dan kelompok perduli lainnya untuk mengefektifkan upaya-upaya penanggulangan kemiskinan.

- Meningkatnya keberadaan dan kemandirian masyarakat serta kapasitas pemerintah daerah dan kelompok perduli setempat dalam menanggulangi kemiskinan di wilayahnya.

Program Penanggulangan Kemiskinan di Perkotaan (P2KP) merupakan program pemerintah yang secara substansi berupaya dalam penanggulangan kemiskinan melalui konsep memberdayakan masyarakat dan pelaku pembangunan lokal lainnya, termasuk Pemerintah Daerah dan kelompok peduli setempat, sehingga dapat terbangun "gerakan kemandirian penanggulangan kemiskinan dan pembangunan berkelanjutan", yang bertumpu pada nilai-nilai luhur dan prinsip-prinsip universal.

\section{P2KP Memfasilitasi Masyarakat serta Pemerintah Daerah Untuk Mampu Menangani Akar Penyebab Kemiskinan Secara Mandiri dan Berkelanjutan}

P2KP meyakini bahwa pendekatan yang lebih efektif untuk mewujudkan proses perubahan perilaku masyarakat adalah melalui pendekatan pemberdayaan atau proses pembelajaran (edukasi) masyarakat dan penguatan kapasitas untuk mengedepankan peran pemerintah daerah dalam mengapresiasi dan mendukung kemandirian masyarakatnya.

Kedua substansi P2KP tersebut sangat penting sebagai upaya proses transformasi P2KP dari 'tataran Proyek' menjadi 'tataran program' oleh masyarakat bersama pemerintah daerah setempat. Bagaimanapun harus disadari bahwa upaya dan pendekatan penanggulangan kemiskinan tidak hanya menjadi perhatian pemerintah pusat, melainkan justru yang terpenting harus menjadi prioritas perhatian dan kebutuhan masyarakat bersama pemerintah daerah itu sendiri.

Substansi P2KP sebagai proses pemberdayaan dan pembelajaran masyarakat dilakukan dengan terus menerus untuk menumbuhkembangkan kesadaran kritis masyarakat terhadap nilai-nilai universal kemanusiaan, prinsip-prinsip kemasyarakatan dan prinsip-prinsip pembangunan berkelanjutan sebagai landasan yang kokoh untuk membangun masyarakat yang mandiri dan sejahtera. Proses pembelajaran di tingkat masyarakat ini berlangsung selama masa Program P2KP 
maupun pasca Program P2KP oleh masyarakat sendiri dengan membangun dan melembagakan Komunitas Belajar Kelurahan (KBK).

Sedangkan substansi P2KP sebagai penguatan kapasitas pemerintah daerah dalam rangka mengedepankan peran dan tanggungjawab pemerintah daerah, dilakukan melalui; pelibatan intensif Pemda pada pelaksanaan siklus kegiatan P2KP, penguatan peran dan fungsi Komite Penanggulangan Kemiskinan Daerah (KPK-D) agar mampu menyusun Dokumen Strategi Penanggulangan Kemiskinan Daerah (SPK-D) dan PJM Pronangkis Kota/Kab berbasis program masyarakat (Pronangkis Kelurahan), serta melembagakan Komunitas Belajar Perkotaan (KBP).

Semua pendekatan yang dilakukan P2KP di atas, ditujukan untuk mendorong proses percepatan terbangunnya landasan yang kokoh bagi terwujudnya kemandirian penanggulangan kemiskinan dan juga melembaganya pembangunan berkelanjutan (sustainable development).

Dengan demikian, pelaksanaan P2KP sebagai "gerakan bersama membangun kemandirian dan pembangunan berkelanjutan yang berbasis nilai-nilai universal " diyakini akan mampu membangun kesadaran kritis dan perubahan perilaku individu ke arah yang lebih baik. Perubahan perilaku individu yang secara kumulatif menimbulkan perubahan kolektif masyarakat inilah yang menjadi inti pendekatan TRIDAYA, yakni proses pemberdayaan masyarakat agar terbangun : daya sosial sehingga tercipta masyarakat efektif, daya ekonomi sehingga tercipta masyarakat produktif dan daya pembangunan sehingga tercipta masyarakat pembangunan yang peduli lingkungan dan prinsipprinsip pembangunan berkelanjutan.

Kondisi yang terjadi bahwa masyarakat harus mau berpartisipasi dalam program pemerintahan. Bentuk partisipasi yang dilakukan masyarakat itu seperti masyarakat diajak untuk menyumbangkan ide / pikirannya pada tahap perencanaan kegiatan yang nantinya akan dilaksanakan. Masyarakat juga diajak untuk membuat keputusan dan pembentukan kepanitian masyarakat yang nantinya akan menjadi perwakilan dari masyarakat dalam kegiatan di program PNPM Mandiri. Bentuk lainnya adalah masyarakat juga bisa memberikan partisipasi dalam bentuk tenaga dan keuangan yang sudah diadministrasikan oleh masyarakat itu sendiri. Hal tersebut terjadi tidak semata - mata berjalan begitu saja akan tetapi diawal pelaksanaan kegiatan, masyarakat diberikan pengarahan dan penyuluhan dari tim pelaksana perubahan terkait pemberdayaan masyarakat. Sehingga masyarakat akan dirubah mindsetnya agar mulai bertanggung jawab terhadap kondisi sosial di lingkungannya, memiliki rasa simpati dan berempati serta mengajak masyarakat untuk berpikir kritis terhadap fenomena yang terjadi di masyarakat tersebut.

\section{Simpulan}

Pemerintah memiliki tanggung jawab besar dalam mengatasi masalah sosial khususnya di masalah kemiskinan. Di sisi lain masyarakat sebagai objek dari kebijakan yang dikeluarkan pemerintah juga memiliki tanggung jawab akan mengatasi masalahnya, jadi dalam mengatasi masalah sosial pemerintah dan juga masyarakat perlu bekerja sama dalam mengatasinya. Karena pemerintah hanya bisa memfasilitasi masyarakat untuk menyelesaikan masalah sosialnya. Tinggal bagaimana respon masyarakat atas fasilitas yang diberikan oleh pemerintah.

Pada kali ini pemerintah mengeluarkan kebijakan PNPM mandiri sebagai sarana untuk masyarakat dalam mempermudah mengatasi kondisi kesulitan yang terjadi di masyarakat. Disini PNPM mandiri memiliki konsep memberdayakan masyarakat, tidak hanya sekedar memberikan bantuan secara pendanaan saja tetapi PNPM mandiri juga mengajari dan membentuk masyarakat untuk bisa mandiri dan bertanggung jawab dalam kondisi yang terjadi di masyarakat serta diajak untuk berpartisipasi aktif dalam program yang diadakan di PNPM mandiri ini. Kesadaran menjadi hal yang penting dalam menyelesaikan masalah sosial ini. Karena dengan menumbuhkan kesadaran pada masyarakat maka pemerintah menjadi terbantu dalam proses mengatasi masalah sosial di masyarakat. Keuntungan yang didapat juga diperoleh kedua pihak, masyarakat juga akan merasakan hak - haknya terpenuhi dan pemerintah menjadi terkurangi beban kerjanya. 


\section{Daftar Pustaka}

Suharto, Edi. 2010. Membangun Masyarakat Memberdayakan Masyarakat "Kajian Strategis Pembangunan Kesejahteraan Sosial dan Pekerjaan Sosial. Bandung : Refika Aditama.

Finna Rizqinna. 2010. Partisipasi Masyarakat. www.lontar.ui.id. Hal 14

Rudito, Bambang dkk. 2003. Akses Peran Masyarakat "Lebih Jauh Memahami Community Develompment". Jakarta : ICSD

Jim Ife .2006. Community Development. Yogyakarta: Pustaka Belajar. Hal 294,295,296,297,

Isbandi Rukminto Adi. Revisi 2012. Pemberdayaan Masyarakat dan Partisipasi Masyarakat. Jakarta: Raja Grafindo Persada. Hal 227,228,229,230,231

Britha, Mikkelsen., Metode Penelitian Partisipatoris dan Upaya-upaya Pemberdayaan: Sebuah Buku Pegangan Bagi Para Praktisi Lapangan, Terjemahan Matheos Nalle, Jakarta: Yayasan Obor Indonesia, 2003 